\title{
FIDUCIARY LAW IN COMMERCIAL RELATIONSHIPS: LUSCAR LTD. v. PEMBINA RESOURCES LTD.
}

\author{
ROBERT G. WARREN *
}

\section{INTRODUCTION}

This comment discusses the ramifications of the decision of the Alberta Court of Appeal in Luscar Ltd. v. Pembina Resources Ltd.' with respect to the law of fiduciary obligation in commercial relationships in the oil and gas industry. Fiduciary law is an important and developing area governing obligations in legal relations where one party is particularly vulnerable to another party's power. The application of fiduciary law to commercial relationships in the oilpatch is not new, ${ }^{2}$ but it is only in the last decade that Alberta courts have been willing to find the existence of fiduciary obligations in such relationships on a regular basis. In Bank of Nova Scotia v. Société General (Canada), ${ }^{3}$ the Alberta Court of Appeal held that the relationship between operators and non-operators under joint oil and gas operating agreements created certain fiduciary duties with respect to the administration and operation of the joint lands. In Erehwon Exploration Ltd. v. Northstar Energy Corp. ${ }^{4}$ and in the trial judgment in Luscar, ${ }^{5}$ the Alberta Court of Queen's Bench held that an Area of Mutual Interest Clause ("A.M.I. Clause") imposed certain fiduciary obligations on a party acquiring an interest in gas or petroleum within the defined area of mutual interest. The application of the law of fiduciary obligation to commercial oil and gas relationships is significant for several reasons. First, commercial relationships in the oil and gas industry are governed by extensively detailed contracts. Consequently, it is often difficult to determine which duties are purely contractual in nature, and which duties are impressed with a higher fiduciary standard. Second, recovery for breach of fiduciary duty can be available in many situations where recovery for breach of contract is not, and different remedies are available for breach of fiduciary duty than for breach of contract. Finally, while players in the oil and gas industry are generally conscious of their contractual obligations, they often do not consider the implications of fiduciary law with respect to their commercial activities until litigation occurs.

In Luscar, the Alberta Court of Appeal revisited the issue of the existence and scope of fiduciary obligations between the operator and non-operator under a joint operating agreement. The Court of Appeal also considered the existence of fiduciary obligations

B.A. (Hons.), LL.B. (Dist.), University of Alberta. Currently articling at Reynolds, Mirth, Richards and Farmer in Edmonton.

(1995), 24 Alta. L.R. (3d) 305, [1995] 2 W.W.R. 153 (Alta. C.A.) [hereinafter Luscar]. All subsequent references are to Alta. L.R. Application for leave to appeal was submitted to the Supreme Court of Canada on February 28, 1995. The status of the leave application was unknown at the date of publication.

2 See e.g. Midcon Oil and Gas Ltd. v. New British Dominion Oil Co. Ltd., [1958] S.C.R. 314, 12 D.L.R. (2d) 705.

3 (1988), 87 A.R. 133, 58 Alta. L.R. (2d) 193 (C.A.).

(1993), 147 A.R. 1, 15 Alta. L.R. (3d) 200 (Q.B.).

(1992), 122 A.R. 83, 85 Alta. L.R. (2d) 46 (Q.B.). 
under an A.M.I. Clause. The Court's conclusions on these matters are important to the oil and gas industry from a practical perspective, but the Court's analysis of fiduciary law in the context of a contractual relationship also has significant ramifications with respect to Alberta fiduciary law generally.

\section{FACTS}

In 1963, Zenmac Metal Mines Ltd., Stanwell Oil \& Gas Ltd. and Ranvik Oils Ltd. entered into an operating agreement for the exploration, development and operation of a petroleum and natural gas lease on certain lands. Each party held a one-third interest in the lease and the lands. Under Clause 18 of the agreement (the A.M.I. clause), the parties agreed that if any party acquired an interest in petroleum within a defined area bordering the joint lands (the area of mutual interest), the acquiring party was required to give written notice to the others and allow them to elect, within thirty days, to purchase an interest in the acquired lands in proportion to their interest in the original joint lands. Through a series of transactions, Pembina Resources Ltd. purchased Zenmac's interest, Luscar Ltd. acquired Stanwell's interest, and Norcen Energy Resources Ltd. acquired Ranvik's interest. Pembina became the manager-operator under the agreement.

In 1971 and 1975, Pembina made acquisitions within the A.M.I., and in 1976 Pembina pooled part of its interest with certain owners of other lands within the A.M.I. to create a spacing unit. As a result of the 1976 pooling agreement, Pembina acquired an interest in other lands within the A.M.I. Pembina did not give notice of these dealings to Luscar or Norcen, contrary to Clause 18. The failure to give notice was an oversight and not due to any fraud or dishonesty on the part of Pembina. The lands acquired by Pembina through these dealings produced petroleum, and by 1990 the lands had generated \$7.6 million in net revenue for Pembina. In 1983, Luscar and Norcen became aware of the acquisitions. In 1986 they commenced an action to recover the opportunity to purchase an interest in the three properties, and to recover their share of the net revenue generated by the properties. They alleged breach of contract, breach of fiduciary duty, breach of trust and unjust enrichment.

At trial, Egbert J. held that Pembina had breached the operating agreement when it failed to give notice of its acquisitions. However, relying on Fidelity Trust Co. v. 98956 Investments Ltd., ${ }^{6}$ he held that the contract action was barred by s. $4(1)(\mathrm{c})$ of the Limitation of Actions Act, $^{7}$ as the acquisitions all occurred more than six years before the action was commenced. Egbert $\mathrm{J}$. also held that a fiduciary relationship arose between the parties pursuant to the operating agreement and the A.M.I. clause. Pembina was found to have breached its fiduciary duty to Norcen and Luscar by failing to give them written notice of its acquisitions in the area of mutual interest, and also by not informing Norcen and Luscar of its own interpretation of geological data gathered from the joint lands. Further, Egbert J. held that the A.M.I. clause created an express or implied trust that arose when Pembina acquired an interest in the A.M.I., and remained 
effective until the plaintiffs, through action or inaction, indicated that they did not wish to participate in the acquisition. Finally, he found that Pembina's failure to give notice resulted in unjust enrichment.

The trial judge held that the actions for breach of fiduciary duty, breach of trust, and unjust enrichment were "equitable grounds of relief"8 within the meaning of s. 4(1)(e) of the Limitation of Actions Act. As such, the six year limitation period for those actions only began to run upon the discovery of the cause of action. He held that the cause of action was not discoverable until 1983. As a result, he concluded that the plaintiff's equitable claims were not statute barred, and imposed a constructive trust on Pembina's interest in the acquired lands in favour of Norcen and Luscar. He also awarded Norcen and Luscar a lump sum for net revenues they would have received had they elected to participate in the acquisition.

Pembina appealed, and argued that the trial judge erred in finding that: (1) there could be concurrent causes of action in equity and contract; (2) Pembina had breached its fiduciary duty; (3) an express or implied trust was created by the contract; (4) unjust enrichment was available; and (5) the facts giving rise to the cause of action were not discoverable until 1983. The Court of Appeal allowed the appeal.

\section{JUDGMENT}

The Court of Appeal held that where there is a truly independent equitable cause of action, "the mere fact that the parties dealt with the matter expressly in their contract does not necessarily mean they intended to exclude the right to sue in equity." Court held that concurrent liability in contract and equity can exist, but only if there is a relationship which imposes equitable duties in the absence of a specific contractual term that creates the same obligation. If such a relationship exists, then the court still must examine the contract to determine whether the parties intended to negate or reduce the equitable obligations.

The Court held that the trial judge erred in finding that Pembina had breached a fiduciary duty in failing to give notice. While the Court confirmed that the relationship between operators and non-operators under a joint operating agreement was a fiduciary relationship, ${ }^{10}$ it noted that not every duty is a fiduciary duty. "The Court concluded that the duty to provide notice of acquisitions within the area of mutual interest was purely contractual and did not fall within the scope of the fiduciary relationship. It outlined three reasons for this finding.

First, the Court found that in the absence of Clause 18, the operator as operator had no obligation to provide any opportunity to the other parties to participate in the 
purchase of adjacent lands. ${ }^{12}$ Second, the Court found that apart from Clause 18, there was nothing in the parties' relationship generally that prevented any of the parties from acquiring adjacent properties without providing the right to participate. ${ }^{13}$ Third, the Court held that the fact that the contract did not suggest that the duties under Clause 18 were fiduciary indicated that the parties intended to reduce all obligations to contractual ones. ${ }^{14}$ Since nothing apart from Clause 18 required an acquiring party to give notice to the other parties, and since Clause 18 itself did not create a fiduciary obligation, ${ }^{15}$ the Court concluded that Pembina's obligations as a fiduciary did not extend to the requirement to give notice of or an opportunity to participate in the acquisition.

The Court of Appeal also held that the trial judge erred in finding that the operator, by virtue of its fiduciary status, had an obligation to provide its own technical analysis and interpretation of geological information obtained in the operation of the joint lands. ${ }^{16}$ The Court then considered whether the trial judge erred in finding that Clause 18 created an express or implied trust. The Court held that the Clause did not use language which clearly showed an intention to create a trust. Rather, the agreement was held to be "a simple contract that carried with it the right to sue for specific performance."17

With respect to the unjust enrichment issue, the Court held that the general test to found a claim in unjust enrichment had not been met. The Court held that failure to give notice of an acquisition did not give rise to an "enrichment" in this context because the party that failed to give notice would be liable for breach of contract. ${ }^{18}$ If, as in this case, the other party did not sue within the limitation period, then there was a juristic justification for the ensuing enrichment: the Limitation of Actions Act. ${ }^{19}$

The Court concluded that, although in certain circumstances concurrent liability in contract and equity can exist, the facts of this case did not give rise to any equitable causes of action. Although unnecessary to decide for the purposes of the appeal, the Court also stated that in its opinion, the facts giving rise to the alleged causes of action were discovered or discoverable at the time the acquisitions were made, and therefore even if the equitable claims had been proven, they would have been statute barred. ${ }^{20}$

Ibid. at 329.

Ibid. at 333-34.

Ibid. at 328, 336 .

Ibid. at 343.

Ibid. at 340-41.

Ibid. at 347.

Ibid. at 349.

Ibid.

Ibid. at 352-57. 


\section{ANALYSIS AND SUMMARY}

This note is concerned with the judgment of the Court of Appeal only as it relates to the law of fiduciary obligation. The balance of the note will discuss the findings of the Court with respect to fiduciary law only.

\section{A. CONCURRENT LIABILITY FOR BREACH OF CONTRACT AND BREACH OF FIDUCIARY DUTY}

The Alberta Court of Appeal held that in certain circumstances, concurrent liability in contract and equity can exist. The conclusion of the Court of Appeal is consistent with that of the Supreme Court of Canada. However, the Alberta Court of Appeal specified different criteria for concurrent liability than did the Supreme Court. The Supreme Court has held, in Canson Enterprises v. Boughton \& Co., ${ }^{21}$ and more recently, in Hodgkinson v. Simms, ${ }^{22}$ that a party can be concurrently liable for breach of contract and breach of fiduciary duty. In Hodgkinson v. Simms, La Forest J., for the majority of the Court said:

I note that the existence of a contract does not necessarily preclude the existence of fiduciary obligations between the parties. On the contrary, the legal incidents of many contractual agreements are such as to give rise to a fiduciary duty. The paradigm example of this class of contract is the agency agreement, in which the allocation of rights and responsibilities in the contract itself gives rise to fiduciary expectations.... In other contractual relationships, however, the facts surrounding the relationship will give rise to a fiduciary inference where the legal incidents surrounding the relationship might not lead to such a conclusion.... However, as Professor Finn puts it, the "end point" in each situation is to ascertain whether "the one has the right to expect that the other will act in the former's interests (or in some instances, in their joint interest) to the exclusion of his own several interests. ${ }^{23}$

The view of the Supreme Court on this issue was that concurrent liability will exist where either the legal incidents of the contract, or the facts surrounding the relationship, give rise to "fiduciary expectations." The Alberta Court of Appeal added an additional element necessary for concurrent liability: the equitable obligation must be independent from the contractual obligation. In other words, in order for there to be concurrent liability for breach of fiduciary duty and breach of contract, either the legal incidents of the contract or the facts surrounding the relationship must give rise to fiduciary duties "in the absence of the specific contractual term that creates the same obligation. ${ }^{24}$

The view of the Alberta Court of Appeal on the issue of concurrent liability can be summarized as follows. Where a contract exists between the parties, concurrent equitable remedies can only be available if the following criteria are met: 
1. There is a relationship between the parties that imposes an equitable duty;

2. The equitable duty exists in absence of the specific contractual term that creates the same obligation. That is, the party must have had an obligation to perform the equitable duty even if the specific contractual term to the same effect did not exist;

3. The terms of the contract must not evidence an intention to negate the equitable obligation.

The view of the Supreme Court, on the other hand, is that only the first and third criteria are necessary for there to be equitable liability concurrent with contractual liability. Far from requiring the equitable obligation to be independent from the contractual one, the Supreme Court has clearly stated that the conferral of power and discretion on one party has the effect of transforming obligations conferred by other methods into fiduciary ones. ${ }^{25}$ While the provisions of the contract are not irrelevant, the Supreme Court of Canada does not require that the fiduciary obligation must exist in absence of the specific contractual obligation, in order for there to be concurrent liability.

In my view, the approach of the Supreme Court of Canada on this issue is more consistent with fiduciary principles. While a term of a contract may specifically negate or reduce fiduciary obligations, a contractual duty should not be held to supplant a more onerous fiduciary duty simply because the contract imposes obligations which would normally exist in any event by virtue of fiduciary law. This was the approach favoured by the Supreme Court with respect to the related issue of concurrent liability in contract and tort, in the recent cases of BG Checo International Ltd. v. B.C. Hydro \& Power Authority ${ }^{26}$ and Queen v. Cognos Inc. ${ }^{27}$ In BG Checo, La Forest and McLachlin JJ. for the majority discussed the effect of a contract on duties imposed by the law of tort:

The mere fact that the parties have dealt with a matter expressly in their contract does not mean that they intended to exclude the right to sue in tort. It all depends on how they have dealt with it.

Viewed thus, the only limit on the right to choose one's action is the principle of the primacy of private ordering - the right of individuals to arrange their affairs and assume risks in a different way than would be done by the law of tort. It is only to the extent that this private ordering contradicts the tort duty that the tort duty is diminished. The rule is not that one cannot sue concurrently in contract and tort where the contract limits or contradicts the tort duty. It is rather that the tort duty, a general duty imputed by the law in all the relevant circumstances, must yield to the parties' superior right to arrange their rights and duties in a different way. In so far as the tort duty is not contradicted by the contract, it remains intact and may be sued upon. For example, where the contractual limitation on the tort duty is partial, a tort action founded on the modified duty might lie. The tort duty as modified by 
the contractual agreement between the parties might be raised in a case where the limitation period for an action for breach of contract has expired but the limitation period for a tort action has not. If one says categorically, as we understand lacobucci $J$. to say, that where the contract deals with a matter expressly, the right to sue in tort vanishes altogether, then the latter two possibilities vanish. ${ }^{2 n}$

\section{And later:}

Generally, the duty imposed by the law of tort can be nullified only by clear terms. We do not rule out, however, the possibility that cases may arise in which merely inconsistent contract terms could negative or limit a duty in tort, an issue that may be left to a case in which it arises. ${ }^{29}$

While the Supreme Court discussed the effect of contract terms on tort duties, the underlying theory of concurrency ought to apply equally to the effect of contract terms on fiduciary duties. Fiduciary duties are imposed where the relationship between the parties is such that one party's interests are vulnerable to the power or discretion exercised by the other party, no matter how that power or discretion is conferred. The fact that the power or discretion is specified by a term of the contract, and is not explicitly declared to be "fiduciary" in nature by the contract, should not in itself prevent the law from protecting the vulnerable party. Further, although parties to a contract have the power to confer respective obligations upon each other on formation of the contract, there are occasions where self-interested parties are justified in entrusting power to a fiduciary. This is especially true where the duties to be performed pursuant to the contract could not otherwise be performed in a commercially efficient manner. Where a court refuses to enforce a duty of loyalty and good faith in such commercial relationships, on the basis that the equitable obligation is not independent from a power or discretion conferred by contract, commercial efficiency is not promoted, it is hindered.

\section{B. EXISTENCE AND SCOPE OF THE FIDUCIARY RELATIONSHIP}

The accepted guidelines for identifying the existence of a fiduciary relationship were first proposed by Wilson J. in her dissenting judgment in Frame v. Smith: ${ }^{30}$

Relationships in which a fiduciary obligation have [sic] been imposed seem to possess three general characteristics:

(1) The fiduciary has scope for the exercise of some discretion or power.

(2) The fiduciary can unilaterally exercise that power or discretion so as to affect the beneficiary's legal or practical interests.

(3) The beneficiary is peculiarly vulnerable to or at the mercy of the fiduciary holding the discretion or power. 
However, not all duties within a fiduciary relationship are fiduciary duties. Where a fiduciary relationship exists on the application of these principles, the next question is whether the scope of fiduciary responsibility extends to the duty which was allegedly breached. Although no test for the scope of the fiduciary relationship has been proposed by the courts, it seems logical that the scope should be determined on the same basis as the existence of the relationship. That is, the question of whether the scope of fiduciary responsibility extends to a particular action is really a question of whether the fiduciary obligation exists in that undertaking. ${ }^{31}$ In my view, the same principles should be applied to both issues. The Alberta Court of Appeal referred to the Frame principles prior to its analysis of Pembina's status as a fiduciary. However, the Court did not explicitly apply the three principles in determining either the existence or scope of Pembina's fiduciary obligations.

The Court of Appeal was primarily concerned with the scope and effect of the terms of the contract. Fiduciary law, on the other hand, is primarily concerned with the circumstances of the parties' relationship. The opinion letter of John Ballem, Q.C., filed as an exhibit and quoted in the trial judgment, succinctly describes the practical relationship between parties in joint oil and gas operations:

Oil companies often find themselves involved with other companies in a vast number of joint operations and joint land holdings. In order to administer their land holdings, oil companies maintain large land departments. The primary task of a land department is to acquire lands on behalf of the company, to see that the company's titles to its properties are maintained in force and not lost through some act of default, and to ensure that their obligations vis-a-vis other joint interest owners are met. The department will not have the capacity, nor the necessary information, to effectively monitor the vast number of land acquisitions that take place on a daily basis throughout Western Canada. ${ }^{32}$

In a further observation in this opinion letter, cited by the Court of Appeal, Mr. Ballem describes the circumstances of the relationship between parties to an A.M.I. clause:

\begin{abstract}
Because of the great number of land transactions which take place within the Province of Alberta each week, and because of the extreme difficulty involved in determining the parties involved in land holdings, which is further complicated by the use of independent land agents, the oil and gas industry has always placed a very high obligation upon the acquiring party to ensure that his acquisitions do not breach the obligation he owes to the joint working interest owners. It is virtually impossible for the non-acquiring parties to monitor the activities of their partners to ensure compliance with the area of mutual interest obligation and, accordingly, the obligation to ensure compliance with the Area of Mutual Interest clause rests squarely upon the acquiring party. ${ }^{33}$
\end{abstract}

The reality of commercial relationships in oil and gas exploration is that it is not commercially reasonable to expect non-acquiring parties to ensure that their partners comply with their obligations under the A.M.I. clause. This reality is underscored in this case by the fact that the original discovery of Pembina's breach of the A.M.I. 
clause was made, not by Luscar or Norcen, but by Pembina. The Court of Appeal found that the plaintiffs ought to have been aware of Pembina's acquisitions, but the opinion of a recognized expert in the industry is to the contrary. On applying the Frame principles to the A.M.I. relationship, in my view it seems clear that each party had the scope for the exercise of some discretion and power in acquiring lands within the area of mutual interest. Further, each party was in a position of vulnerability in being unable, for practical purposes, to monitor the others and ensure that they complied with their obligations under Clause 18. The relationship between the parties thus meets the first and third criteria set out in Frame.

With respect to the second criterion, it is evident that an acquisition of lands within the A.M.I. also affected the non-acquiring parties' practical interests. The rationale behind the creation of an A.M.I. is that petroleum and natural gas are fugacious substances, and that the reserviors do not occur in conformity with legal boundaries. As such, if a party were to acquire adjacent lands, it could drain the substances (and thus the value) from the joint lands. With respect, Pembina's fiduciary obligation likely should have been extended to acquisitions within the area of mutual interest, even on the modified test for concurrent liability adopted by the Court of Appeal. Even in the absence of Clause 18, Luscar and Norcen's practical interests were vulnerable to Pembina's discretion in acquiring adjacent lands. Pembina's position as operator, and its access to geological information which was unavailable to Luscar and Norcen except through Pembina, only compounded the latter parties' vulnerability.

The Court of Appeal also found that a non-acquiring party was not vulnerable because it could bring action under the contract. ${ }^{34}$ But if Mr. Ballem is correct in his opinion that it is not possible from a practical point of view for a non-acquiring party to ensure that the acquiring party complies with the A.M.I. clause, then it may not be possible from a practical point of view to bring action under the contract within the limitation period, if ever. The difficulty of discovering a breach of an A.M.I. clause not only indicates the degree of vulnerability of the non-acquiring party, it also justifies an extension of the limitation period in this case for breach of fiduciary duty by use of the discovery rule.

The Court of Appeal also held that, "had the parties wished, they could have specifically provided that a failure to give notice ... created a fiduciary duty." ${ }^{35}$ With respect, this statement is a misinterpretation of fiduciary principles. According to the Supreme Court, a fiduciary duty arises only by virtue of the factual position of the parties. While parties can negate fiduciary duties through specific contractual provisions to that effect, they surely cannot create fiduciary duties simply by agreeing between themselves that fiduciary duties exist. If, on an explicit application of the Frame principles, no fiduciary obligation is found to exist, then a provision in the contract to the contrary ought to be irrelevant. By the same token, if a fiduciary obligation is found to exist on the principles, then a provision in the contract to that effect is simply 
redundant. To hold otherwise undermines fiduciary principles to the detriment of those who most need their protection.

Finally, from a practical point of view one of the more important ramifications of the Luscar case is that the Court of Appeal definitively answered the question it posed in Trilogy Resource Corporation v. Dome Petroleum Ltd $^{36}$ It is now clear that an operator has no obligation to supply its analysis of geological information to the other parties to the operating agreement. On an application of fiduciary principles, this seems to be the correct view. The non-operator is not vulnerable to the operator in terms of the operator's control over its own interpretations of geological data. In the absence of a contractual term to the contrary, the operator ought only to be obliged to ensure that it provides raw geological data to the non-operator quickly and accurately. 